\title{
Challenges for a second decade of ubimus research: Knowledge transfer in ubimus activities
}

\author{
Damián Keller (Amazon Center for Music Research - NAP, \\ Federal University of Acre and Federal Institute of Acre, Rio Branco, Acre, Brazil) \\ dkeller@ccrma.stanford.edu
}

\begin{abstract}
This is the second part of a discussion on the challenges of a second decade of ubimus research. I discuss the issues involved in supporting knowledge transfer in musical activities. I lay out and exemplify the concept of metaphor for creative action. I summarize the results of three studies employing the time tagging metaphor, configuring an effective strategy for supporting everyday musical creativity. Then I report results of a study employing the stripe metaphor - an extension of time tagging devised for usage of a large number of resources. Twelve subjects, encompassing musicians and casual participants, realized improvisatory sessions in a non-standard setting - an audio and musical equipment store. The results indicated a promising new avenue of research targeting lay-musician interaction. The results also raised new questions regarding the strategies adopted for knowledge transfer support. The last section of the paper places these results within the context of the ongoing ubimus efforts, highlighting four issues that have emerged as viable research avenues: everyday musical creativity, lay-musician interaction, design for sustainability and design for distributed creativity.
\end{abstract}

Keywords: Ubiquitous music, Everyday creativity, Metaphors for creative action, Lay-musician interaction.

Desafíos para a segunda década de pesquisa ubimus: Transferência de conhecimento nas atividades musicais ubíquas Resumo

Nesta segunda parte da discussão sobre os desafios da segunda década de pesquisa em música ubíqua, discuto diversas questões relacionadas à transferência de conhecimento nas atividades musicais. Documento e exemplifico o conceito de metáfora para a ação criativa e resumo os resultados de três estudos que empregam a metáfora de marcação temporal, confirmando a aplicabilidade dessa metáfora no apoio à criatividade musical cotidiana. Na seção seguinte, relato os resultados de um estudo que emprega a metáfora da listra - uma extensão da marcação temporal concebida para o uso de grandes quantidades de recursos. Doze sujeitos, abrangendo músicos e participantes casuais, realizaram sessões improvisatórias em um ambiente não planejado para o fazer musical - uma loja de equipamentos de áudio e música. Os resultados apontaram uma nova linha de pesquisa envolvendo a interação leigo-músico. Os resultados trouxeram novos questionamentos sobre as estratégias adotadas para o suporte à transferência de conhecimento. A última seção do artigo coloca esses resultados no contexto dos atuais esforços em ubimus, destacando quatro questões que configuram questões de pesquisa viáveis: a criatividade musical cotidiana, a interação leigo-músico, o design para a sustentabilidade e o design para a criatividade distribuída.

Palavras-chave: Música ubíqua, Criatividade cotidiana, Metáforas para a ação criativa, Interação leigo-músico.

\section{Introduction}

In 2009, after two years of intense exchange - led by two Brazilian research groups, NAP (UFAC/IFAC) and LCM (UFRGS) - the initial proposal on ubiquitous music research (ubimus) was laid out in a series of papers and artworks presented at the Congress of the ANPPOM (KELLER et al. 2009a) and at the Brazilian Symposium on Computer Music (KELLER et al. 2009b; PIMENTA et al. 2009). Subsequently, case studies and artistic products were presented as invited exhibits, talks and panels at the Biennial of Latin American Art in Denver, Colorado (2013), ANPPOM (2014), SIMA (2015) and SEMPEM (2016). Special volumes were published by Sonic Ideas (2013), Cadernos de Informática (2014) and Scientia Tech (2015). Aside from the multiple chapters and papers that have appeared in specialized publications over the last few years - such as the Journal of New Music Research, Organised Sound, and the Journal of Music Technology and Education - a reference volume was released by Springer Press in 2014. Hence, I believe we can say that ubiquitous music constitutes a consolidated research field. 
One of the objectives of ubimus endeavors is to provide access to creative music making for a wide range of participants. Supporting good-quality musical products without creating unnecessary barriers to novice participation is particularly tricky. Hence, ubimus research has yielded alternative approaches, including the development of creativity support metaphors. These metaphors can be used to guide the implementation of technological infrastructure. Whether the metaphors are effective means of support for creative activities demands experimentation and data collection in real settings. Consequently, ubimus studies deal with the assessment of creative products and of creative processes while subjects carry out musical activities in everyday contexts.

In this paper, I summarize and discuss the results of field studies employing time tagging (KELLER et al., 2010) and report results of a study employing the stripe metaphor (FARIAS et al., 2014). Firstly, I lay out the concept of metaphor for creative action. This is intrinsically linked to ubimus research, and to the best of my knowledge, it has not been articulated in related fields - including computer music, creativity studies or human-computer interaction. The second section of the paper provides a short description of the time tagging metaphor and summarizes the experimental findings of three ubimus studies, highlighting the limitations of the initial implementations. Part of these limitations are addressed by the second generation of mixDroid prototypes, embodying the stripe metaphor. Access to massive resources is one of the factors considered in this new set of support tools. I report a study involving both musically trained and lay subjects in everyday settings. A boosted level of engagement in lay-musician interaction emerges as one of the key findings of the experiment. How this phenomenon is linked to the participation of both musicians and naive subjects is an experimental question that demands further study. In the last section of the paper, I place these issues within the larger context of future research endeavors in ubimus. Both everyday musical creativity and lay-musician interaction are new avenues of research that demand an expansion of music-theoretic and methodological frameworks (KELLER; LAZZARINI, 2017). Mainstream musical interaction research has inherited a restricted view of music making that revolves around concepts such the instrument, the orchestra and the score - well-suited for nineteenth-century European musical practices but hardly applicable to twenty-first century musical endeavors. The adoption of acoustic-instrumental social practices for technology-based music making dismisses two factors that constrain the creative processes and introduce new demands in the design of support infrastructures: distributed creativity and sustainability. Engaging with distributed creativity implies designing for multiple stakeholders carrying out activities in a variety of settings. These activities might take place in well-trodden musical venues - such as auditoriums, rehearsal spaces and classrooms - but they might also be carried out in everyday contexts, including transitory, domestic, leisure and work environments not designed for artistic usage. Engagement of casual participants becomes one of the key issues to be dealt with in these settings. Long-term musical training, domain-specific knowledge and expensive, specialized equipment are not viable options in these types of contexts. Therefore, sustainability encompassing infrastructure with low financial cost, easy access to tools and community-shared knowledge - becomes an important target of the support strategies.

Before tackling the recent developments in ubimus research, it may be useful to establish the differences of this perspective in relation to other musical interaction proposals. My keynote talk at the Brazilian Symposium of Computer Music held in 2017 in São Paulo was received with a mix of disbelief and rejection. On one hand, anonymous reviewers pointed to laptop and mobile orchestras as a step forward from ubimus proposals. From a different but conceptually akin perspective, other researchers indicated that the creative 
products yielded by ubimus activities were not music at all. I will address these two criticisms. I will also argue that it is not sufficient to provide means to make the same music Europeans were doing two hundred years ago. Ubiquitous music research is not just yet another approach to musical interaction. It is a new way to foster music making in contexts that were previously not accessible to artistic endeavors.

\section{Musical interaction and knowledge transfer}

Among the issues addressed by ubimus research, the mechanisms of knowledge production and transfer may impact non-professional manifestations of creative practice. The idea that some forms of knowledge are not amenable for sharing has gained acceptance since Polanyi's (1958) initial formulation of the concept of tacit knowledge. Based on a survey of sixty knowledge-management papers, Grant (2007) analyzes the impact of the tacit knowledge concept and proposes a model based on Polanyi's work. Grant's (2007) model adopts Polanyi's basic precept that all knowledge includes a degree of tacitness. Hence, a continuum between tacit and explicit states provides a better representation than the either/ or usage found in other proposals of knowledge management through information technology. Grant's survey indicates that the adoption of an overly simplistic view of the tacit/explicit dimension leads to significant failures in knowledge management practice, especially in IT-related projects. His model includes contexts suitable for stakeholders with a limited background experience (with little tacit knowledge), settings where experts with shared backgrounds and experience can make full use of their tacit knowledge, situations featuring personal knowledge that can hardly be made explicit, and cases in which the stakeholders cannot articulate their knowledge (labeled 'ineffable').

Rather than equating tacit to implicit knowledge, Grant suggests that implicit knowledge might be described as tacit knowledge with potential to be made explicit. For example, a community that shares the necessary know-how to achieve a goal may use that know-how as a way to avoid making their knowledge explicit through spoken or written language. The use of explicit representations - such as verbal explanations, graphic depictions or the implementation of symbolic systems - depends on the level of specialization of the shared resources. Within a common domain, experts have a large pool of shared tacit resources. Beginners, on the other hand, rely on the use of broadly shared knowledge, such as natural language, to eventually gain access to implicit resources.

Knowledge transfer is an important aspect of artistic practice, but no less important is the generation of new - original and relevant - knowledge through shared experience (Dewey, 1934). The processes involved in the production of new knowledge, encompassing both activities and results, have been dealt with within the context of creativity studies (Kozbelt et al., 2010). A recent categorization of general creativity magnitudes fits well within the dimensions of knowledge proposed by Grant and Polanyi. Following (BEGHETTO; KAUFMAN, 2007; KAUFMAN; BEGHETTO, 2009) four levels of creative magnitude have been proposed: eminent creativity (Big-C), professional creativity (pro-C), everyday creativity (little-C) and personal creativity (mini-c) (KOZBELT et al., 2010, p. 23). Big-c or eminent creativity encompasses manifestations socially established as paradigmatic examples of creative results, such as published works of art and scientific theories. Eminent creativity manifestations target professional creative products that involve wide social exposure. Personal experiences leading to creative products fall within the context of everyday or little-c creativity studies (RICHARDS et al., 1988). Mini-c creativity is characterized by the internal, subjective and emotional impact of everyday creative practice. Thus, the little-c label is 
reserved for everyday creative phenomena that yield products. Between the little-c and the Big-c phenomena, Kaufman and Beghetto (2009) suggest a third type of creative behavior and products: professional creativity or pro-c, encompassing creative achievements that do not attain the eminence of Big-c manifestations. Both pro-c and Big-c processes require explicit knowledge only accessible to experts. The difference between these two magnitudes can be gauged by the social impact of the creative outcomes.

While musical creativity has traditionally been equated to sonic outcomes, the relationship between the material resources and the cognitive processes leading to those outcomes has only recently been addressed - see (KELLER et al., 2009a) and (KELLER et al., 2014b) for reviews of musical creativity theories. How to share tacit knowledge remains one of the issues to be tackled by musical interaction research. Within the context of musical practice, Big-c products are usually surrounded by a large production of explicit knowledge in the form of written discussions, analyses and derivative works (SIMONTON, 1990). This body of knowledge is intended to facilitate access to meaningful musical experience. Pro-c products also rely on a fair amount of extra-musical knowledge, but in this case implicit knowledge involving specialized skills in listening and sound making play a key role. Everyday musical creative phenomena are characterized by non-technical settings and by the participation of casual stakeholders (KELLER et al., 2014b; KELLER; LIMA, 2016). Therefore, little-c music making does not require specialized knowledge and frequently relies on local resources and personal experience, reducing the demands of tacit knowledge to achieve creative results. Contrastingly, the ineffable quality of tacit knowledge characterizes mini-c musical phenomena.

There are at least two approaches to musical interaction design that engage with knowledge transfer mechanisms during creative activities: the acoustic-instrumental paradigm and the ubimus perspective (table 1). These two approaches involve very different types of knowledge. Hence, the specific requirements are also very different. While acoustic-instrumental designs strive to support virtuosic performances (TANAKA, 2009; WESSEL; WRIGHT, 2002), ubimus designs embrace manifestations of everyday creativity (KELLER; LIMA, 2016; PINHEIRO DA SILVA et al., 2013). Acoustic-instrumental designs rely on explicit symbolic notation and/or extensive exposure to specialized instrumental practice. Ubimus designs rely on opportunistic usage of local social and material resources. The latter strategy is grounded on a growing awareness of the impact of everyday musical activities on social interactions and of the long-term consequences of musical endeavors on the local resources. Sustainability emerges as one of the key challenges for ubimus research.

Table 1. Comparison of two musical interaction design methods: the acoustic-instrumental paradigm and the ubimus paradigm.

\begin{tabular}{|c|c|c|}
\hline features & acoustic-instrumental approach & ubimus perspective \\
\hline creativity magnitude & professional & everyday \\
\hline knowledge support & domain specific & genal \\
\hline time investment & long term & creative planning and execution \\
\hline profile of activities & instrumental performance & layple, lay-musician interaction \\
\hline profile of subjects & musicians & local sounds, repurposed infrastructure \\
\hline typical resources & acoustic instrumental concepts, symbolic & nes \\
\hline focus on sustainability & notion & \\
\hline
\end{tabular}




\section{Metaphors for creative action}

Creativity support metaphors furnish a contact point between musical interaction metaphors (PIMENTA et al., 2012) and the approaches to creativity laid out in interaction aesthetics (KELLER et al., 2015b). Metaphors for creative action differ from domain-specific musical interaction metaphors (see the proceedings of the NIME conferences for multiple examples of the latter). While musical interaction metaphors strive to provide support for musicians within the context of executive activities, metaphors for creative action strive to increase the participants' creative potentials. Hence, they are applicable to a variety of design activities, including planning and exploration. Creative potentials can impact the intended and the unintended by-products of the activity. So they not only target explicit cognitive processes. Metaphors for creative action may find application when the activity demands usage of tacit knowledge.

The creativity support metaphors described in the following sections - time tagging and the stripe metaphor - employ designs based on ecologically grounded strategies (KELLER, 2000; KELLER et al., 2010). Time tagging uses sonic cues as proxies for the temporal distribution of sonic events. The next section provides multiple examples of experiments that employ time tagging and the stripe metaphor for mixing sonic resources (table 2).

\section{Time tagging experiments}

Two generations of prototypes were designed and deployed (FARIAS et al., 2014; RADANOVITSCK et al., 2011). As an initial validation process, Keller et al. (2009a) used an emulation of a first-generation mixDroid prototype (mixDroid $1 G$ ) for the creation of a complete musical work. The procedure encompassed several mixing sessions. The mixDroid $1 \mathrm{G}$ prototype was used in the emulation mode on a laptop computer and was activated through pointing and clicking with an optical mouse. Several dozens of sound samples were used, with durations ranging from less than a second to approximately two minutes. The temporal structure of the mix was based on the temporal characteristics of the sonic materials (biophonic sounds). The result was a seven-minute stereo sound work - Green Canopy On The Road - the first documented ubiquitous music work, premiered at the twelfth Brazilian Symposium on Computer Music, held in Recife, PE (KELLER et al., 2009b).

Focusing on the demands of naive participants in everyday contexts, a second study (PINHEIRO DA SILVA et al., 2014) comprised creative activities in public settings - at a shopping mall, at a busy street and in a quiet area featuring biophonic sounds - and in private settings - at the home of each participant and at a studio facility. Six subjects participated in 47 mixing sessions using samples collected at two outdoors sites comprising urban sounds and biophonic sources. Creativity support was evaluated by means of a creative-experience protocol encompassing six factors: productivity, expressiveness, explorability, enjoyment, concentration, and collaboration (CSI-NAP v. 0.1 - KELLER et al., 2011b). Outdoor sessions yielded higher scores in productivity, explorability, concentration and collaboration when compared to studio sessions. Compound effects of sound sample type and activity location were observed in the explorability factor when biophonic sound samples were used. Similar effects were detected on explorability, productivity and concentration in the conditions employing urban sounds.

A third study (KELLER et al., 2013b) made use of recorded vocal samples created by the participants. In order to untangle the effects of place and activity type, three conditions were studied: place, including domestic and commercial settings; activity type, i.e., 
imitative mixes and original creations; and body posture, realizing the mix while standing or sitting. Ten subjects took part in an experiment encompassing 40 interaction sessions using mixDroid. Subjects created mixes and assessed their experiences through a modified version of the CSI protocol applied in the previous studies (KELLER et al., 2011b). Explorability and collaboration factors yielded superior scores when the activities were carried out in domestic settings.

The results highlighted the impact of the venue on the support of everyday creative experiences. The outdoor spaces were preferred by the participants of the second study and domestic settings got slightly higher ratings in the third study. While the profile of the subjects impacted the outcome of the third study, this trend was not confirmed by the second study's results. Hence, the main conclusion to be drawn from these studies points to the impact of the venue on the subjects' evaluation of the creative experience. Both their ability to explore the potential of the support metaphor and their ability to collaborate were boosted by domestic settings and by outdoor settings.

Table 2. Time tagging studies.

\begin{tabular}{|c|c|c|c|c|c|c|}
\hline publication & $\mathbf{N}$ & subjects & settings & $\begin{array}{l}\text { activities, } \\
\text { features }\end{array}$ & + & - \\
\hline $\begin{array}{l}\text { Radanovitsck et } \\
\text { al. 2011, SBCM }\end{array}$ & 6 & $\begin{array}{l}\text { adults, males, } \\
24 \text { yrs., wi- } \\
\text { th tech expe- } \\
\text { rience }\end{array}$ & lab & $\begin{array}{l}\text { selection of } \\
\text { samples, imita- } \\
\text { tion of model, } \\
\text { comparison wi- } \\
\text { th Kristal }\end{array}$ & $\begin{array}{l}\text { short duration of } \\
\text { imitation tasks }\end{array}$ & $\begin{array}{l}\text { long duration of } \\
\text { selection tasks }\end{array}$ \\
\hline $\begin{array}{l}\text { Keller et al. } \\
\text { 2013a, ANPPOM }\end{array}$ & 10 & $\begin{array}{l}\text { mostly males, } \\
23,55 \pm 4,79 \\
\text { yrs, mostly } \\
\text { novices }\end{array}$ & $\begin{array}{l}\text { domestic, } \\
\text { commer- } \\
\text { cial }\end{array}$ & $\begin{array}{l}\text { CSI,-NAP vo- } \\
\text { cal percussive } \\
\text { sounds }\end{array}$ & $\begin{array}{l}\text { musicians better } \\
\text { on } 6 \text { factors; } \\
\text { body posture: no } \\
\text { effect }\end{array}$ & $\begin{array}{l}\text { domestic place: } \\
\text { better on explora- } \\
\text { bility, fun, colla- } \\
\text { boration }\end{array}$ \\
\hline $\begin{array}{l}\text { Keller et al. } \\
\text { 2013b, SBCM }\end{array}$ & 12 & $\begin{array}{l}6 \text { males, } 6 \text { fe- } \\
\text { males, adults, } \\
\text { novices }\end{array}$ & $\begin{array}{l}\text { domestic, } \\
\text { commer- } \\
\text { cial }\end{array}$ & $\begin{array}{l}\text { CSI-NAP, do- } \\
\text { mestic sounds }\end{array}$ & $\begin{array}{l}\text { commercial place: } \\
\text { more original pro- } \\
\text { ducts, more cogni- } \\
\text { tive effort; } \\
\text { body posture: no } \\
\text { effect }\end{array}$ & $\begin{array}{l}\text { domestic pla- } \\
\text { ce: low cogniti- } \\
\text { ve effort, engage- } \\
\text { ment, fun collabo- } \\
\text { ration }\end{array}$ \\
\hline $\begin{array}{l}\text { Ferreira et al. } \\
\text { 2014, SIMA }\end{array}$ & 12 & $\begin{array}{l}6 \text { males, } 6 \text { fe- } \\
\text { males, adults, } \\
4 \text { musicians }\end{array}$ & $\begin{array}{l}\text { domestic, } \\
\text { commer- } \\
\text { cial }\end{array}$ & $\begin{array}{l}\text { CSI-NAP, do- } \\
\text { mestic sounds, } \\
\text { one and two- } \\
\text {-subject acti- } \\
\text { vities }\end{array}$ & $\begin{array}{l}\text { one-subject activi- } \\
\text { ties: less cognitive } \\
\text { effort; } \\
\text { commercial pla- } \\
\text { ce: more cognitive } \\
\text { effort, more origi- } \\
\text { nal products }\end{array}$ & $\begin{array}{l}\text { two-subject activi- } \\
\text { ties: more original } \\
\text { products, better } \\
\text { on engagement, } \\
\text { fun, collaboration }\end{array}$ \\
\hline $\begin{array}{l}\text { Pinheiro da Silva } \\
\text { et al. } 2013 \text {, } \\
\text { Musica Hodie }\end{array}$ & 6 & $\begin{array}{l}2 \text { males, } 6 \text { fe- } \\
\text { males, } 2 \text { no- } \\
\text { vices, } 4 \text { musi- } \\
\text { cians }\end{array}$ & $\begin{array}{l}\text { lab, street, } \\
\text { biophonic } \\
\text { settings }\end{array}$ & $\begin{array}{l}\text { CSI-NAP v. 0.1, } \\
\text { urban soun- } \\
\text { ds, biophonic } \\
\text { sounds }\end{array}$ & $\begin{array}{l}\text { outdoor settings: } \\
\text { better on explora- } \\
\text { bility, fun, collabo- } \\
\text { ration }\end{array}$ & $\begin{array}{l}\text { lab settings: mo- } \\
\text { re relevant pro- } \\
\text { ducts, less cogniti- } \\
\text { ve effort }\end{array}$ \\
\hline
\end{tabular}

\section{Fostering professional creativity in everyday settings, the stripe}

Despite the positive outcomes of the experiments involving time tagging support for novices, no attempt was made to address the needs of professional participants. Given 
the different requirements of musicians and non-musicians (LIMA et al., 2012), it would not be surprising to find that effective support for novices does not meet the expectations of professional usage. In this section, I describe a new metaphor based on time tagging and a methodological strategy that incorporates an ecology of devices to support creative activities by both musicians and laypeople in everyday settings.

Our team found inspiration in the work of Hungarian-French visual artist Victor Vasarely (1906-1997). Vasarely defined the field of Optical Art (op art). Vasarely and the op artists strived to find perceptual principles to display simple visual information that would trigger a direct aesthetic impact. His proposals influenced a generation of artists, including the Argentinean Julio Le Parc, the Venezuelan Jesús Rafael Soto and Vasarely's own son Jean-Pierre Yvaral. His innovative paintings and sculptures made use of geometric shapes to create visual illusions. Some of his works, use bicolor stripes to suggest overlapping layers and movement. In the Yellow Manifesto, written in 1955, he stated that "painting and sculpture [have] become anachronistic terms: it's more exact to speak of bi-, tri- and multidimensional plastic art. We no longer have distinct manifestations of a creative sensibility, but the development of a single plastic sensibility in different spaces." (VASARELY, 1955). We applied op-art concepts to expand the time tagging metaphor.

The second generation of mixDroid prototypes features a new interaction mechanism: the stripe (figure 1). The stripe acts as a functional unit that features both interaction support and audio manipulation. This metaphor ties to the sonic sample the functionality previously linked to the audio channel in analogue systems. The objective is to allow for synchronous interaction with a large number of elements to overcome the screen-size limitations of small devices. Stripes enable mixing using both hands. The amount of active stripes depends on the device's computing power and on the participant's cognitive abilities. Thus, similarly to previous time-tagging implementations (RADANOVITSCK et al., 2011), devices with low computational resources can be used for complex creative activities in everyday contexts.

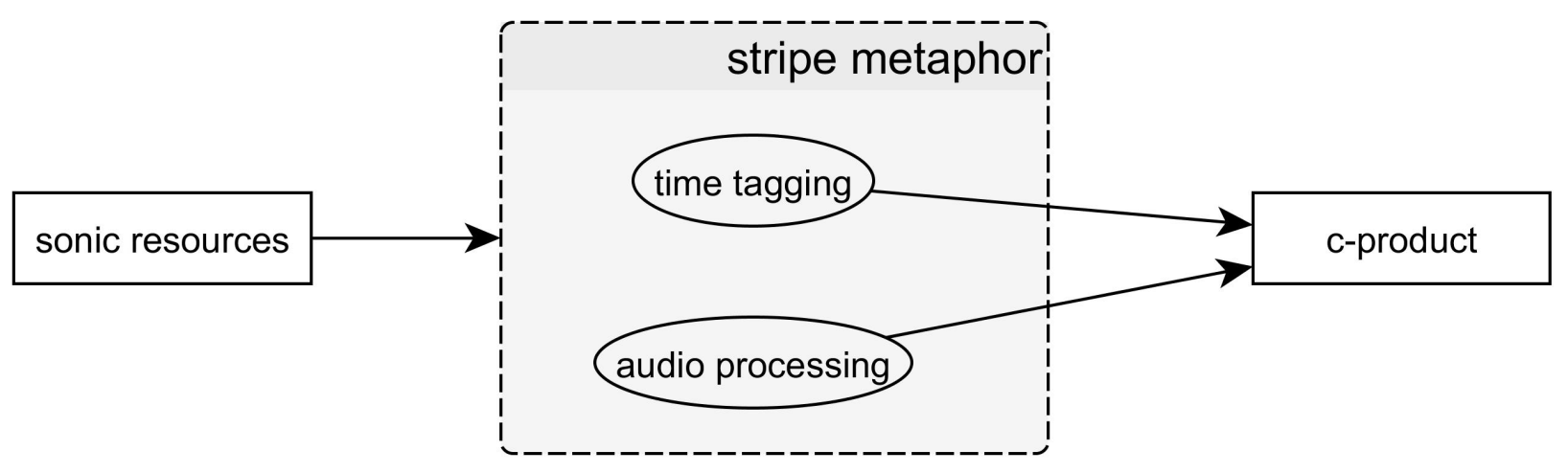

Figure 1. The stripe metaphor: bringing together audio processing and creative decision making on a single functional unit.

The stripe acts as an entry point to the sound data. Each stripe displays basic information on the sonic sample being handled, including the file name, the total running time, the current time and the execution state (FARIAS et al., 2014) (see figure 3). Each sound file linked to a stripe is processed independently. By linking the interaction mechanism with the sound sample, the stripe releases the user from the requirement of dealing with multiple samples as a block (as it is the case in the mixing-console metaphor that has the audio channel as its basic functional unit). Synchronous mixing of multiple sound sources is supported without compromising the parametric independence of each source. From the 
perspective of the user, sounds that demand fast interaction can be placed on stripes that are close to each other. This flexibility, combined with the ability to select stripes though scrolling, should grant quick access to a large number sonic items.

Table 3. Stripe metaphor studies.

\begin{tabular}{|c|c|c|c|c|c|c|}
\hline publication & $\mathbf{N}$ & subjects & settings & activities, features & + & - \\
\hline $\begin{array}{l}\text { Farias et al. } \\
2014\end{array}$ & 24 & $\begin{array}{l}\text { mostly males, } \\
\text { average } \\
\text { age } 30 \text { yrs., } \\
\text { technology } \\
\text { students }\end{array}$ & $\begin{array}{l}\text { school } \\
\text { lab }\end{array}$ & $\begin{array}{l}\text { product } \\
\text { evaluation: } \\
\text { Audacity ( } 97 \\
\text { minute activity), } \\
\text { mixDroid } 1 \mathrm{G} \\
\text { (6:30 min.), } \\
\text { mixDroid } 2 \mathrm{G} \text { ( } 3: 30 \\
\text { min.), urban and } \\
\text { domestic samples }\end{array}$ & $\begin{array}{l}\text { same profile for mixDroid } 1 \mathrm{G} \\
\text { and mixDroid } 2 \mathrm{G} \text { products; } \\
\text { mixDroid } 2 \mathrm{G} \text { product: more } \\
\text { relevant than Audacity } \\
\text { product }\end{array}$ & $\begin{array}{l}\text { Audacity } \\
\text { product: } \\
\text { more } \\
\text { relaxing, } \\
\text { more } \\
\text { pleasant; } \\
\text { slightly } \\
\text { more } \\
\text { original, } \\
\text { slightly } \\
\text { more } \\
\text { expressive }\end{array}$ \\
\hline $\begin{array}{l}\text { Pereira et } \\
\text { al. 2015, } \\
\text { CLAM }\end{array}$ & 10 & $\begin{array}{l}6 \text { females, } \\
4 \text { males, } \\
\text { average age } 30 \\
\text { yrs., } 4 \text { Down } \\
\text { Syndrome, } \\
6 \text { cognitive } \\
\text { deficiencies }\end{array}$ & $\begin{array}{l}\text { school } \\
\text { settings }\end{array}$ & $\begin{array}{l}\text { exploration } \\
\text { (no time limit), } \\
\text { creation (1 } \\
\text { minute), small } \\
\text { number of } \\
\text { samples }\end{array}$ & $\begin{array}{l}\text { positive evaluation of fun, } \\
\text { collaboration; } \\
\text { relevant products }\end{array}$ & $\begin{array}{l}\text { difficulties } \\
\text { in data } \\
\text { collection }\end{array}$ \\
\hline $\begin{array}{l}\text { Silva et al. } \\
\text { 2016, SIMA }\end{array}$ & 17 & $\begin{array}{l}\text { Ages: 8-11 } \\
\text { yrs., novices, } 3 \\
\text { years average } \\
\text { of mobile } \\
\text { device usage }\end{array}$ & $\begin{array}{l}\text { school } \\
\text { lab }\end{array}$ & $\begin{array}{l}\text { exploration, } \\
\text { creation, one } \\
\text { and two-subject } \\
\text { activities; use } \\
\text { of facial icons } \\
\text { (3-point Likert } \\
\text { scale) }\end{array}$ & $\begin{array}{l}\text { solo exploration: relevant } \\
\text { products, positive evaluations } \\
\text { of fun, collaboration; low } \\
\text { cognitive effort; duo activities: } \\
\text { better results than solo in } \\
\text { product relevance, fun, } \\
\text { collaboration; lower cognitive } \\
\text { effort }\end{array}$ & $\begin{array}{l}\text { no relevant } \\
\text { results with } \\
\text { the } 4-7 \text { year } \\
\text { group }\end{array}$ \\
\hline
\end{tabular}

\section{Provocative Synthesis II: a stripe metaphor study}

The study Provocative Synthesis II addressed the impact of the stripe metaphor in musical activities involving both musicians and novices. As part of a series of ubimus experiments devised by the musician Edemilson Ferreira (FERREIRA et al., 2015; KELLER et al., 2013a), this study encompassed musicians performing amplified electric instruments and casual users triggering audio sequences on mixDroid $2 \mathrm{G}$ CS.

Settings and equipment. The study was carried out at an audio and musical equipment store located in downtown Rio Branco, AC, Brazil. The hardware included a portable computer, a six-channel JamHub mixer and stereo headphones for each of the participants. The JamHub system (WHITE, 2010) features independent returns through headphones for each user. The output from the mixer was routed to the computer and sound levels were monitored by the researcher (figure 2). The prototype mixDroid 2G CS was used on an Iconia One Acer tablet, running the Android 4.1 operating system. The musicians played electric guitar and electric bass.

Subjects profile. Twelve subjects participated in the sessions, including 6 musicians and 6 laypeople (table 4). Their average age was 28.5 years with a standard deviation of 6.76 years. Three of the six self-described musicians had no formal study but reported ten or more years of proficiency playing either electric bass or electric guitar. 


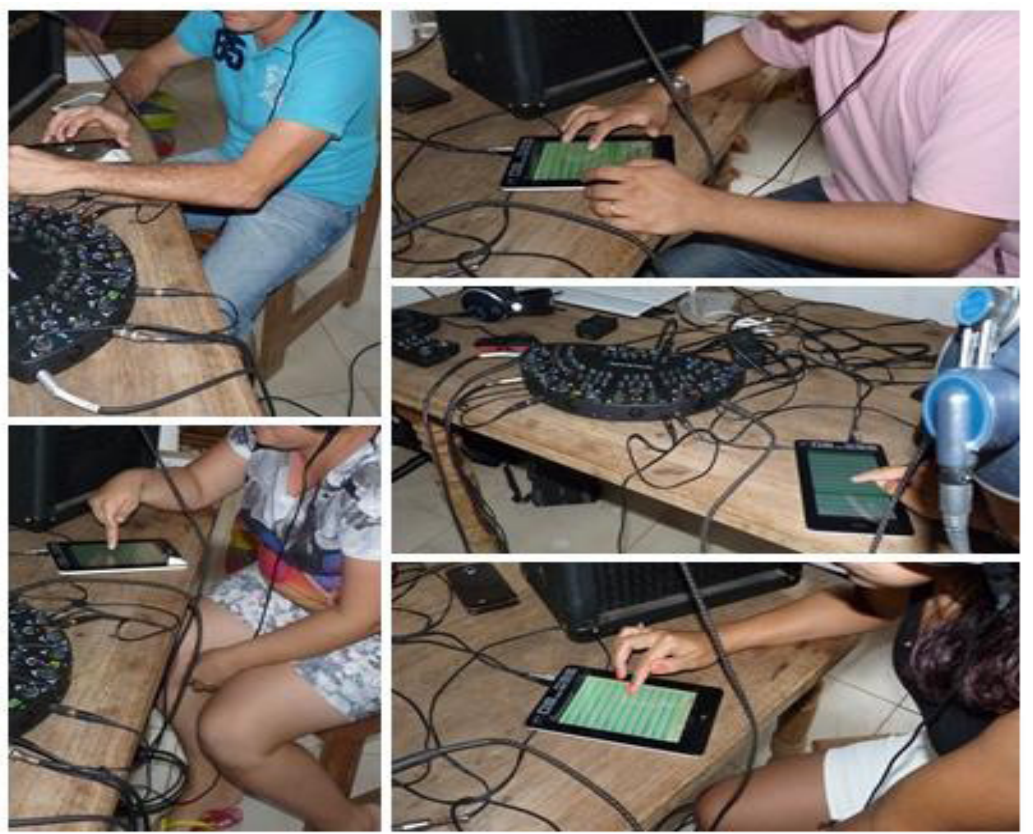

Figure 2. Subjects participating in Provocative Synthesis II at an audio and music equipment store.

Table 4. Profile of the subjects.

\begin{tabular}{ccccccc}
$\mathbf{N}$ & age & men & women & musicians & non-musicians & formal study \\
\hline 12 & $28.5 \pm 6.76$ & 7 & 5 & 6 & 6 & 3 years \\
\hline
\end{tabular}

Procedures. The eleven improvisational sessions had an average of 4 participants per session. Each activity lasted approximately two minutes. Lay participants sat on benches, while the musicians preferred to play standing. Musicians were free to improvise within the bounds of the rhythmic reference laid out by the soundtrack and by the verbal instructions. Throughout the sessions, the mixDroid player was responsible to start the sonic exchanges. All sonic results were recorded as PCM uncompressed audio files.

As in previous creativity assessment experiments (FARIAS et al., 2014; LIMA et al., 2012; PINHEIRO DA SILVA, 2013), our research team employed the protocol CSI-NAP to collect data on the creative activity and the creative products. Two factors assess the creative products (relevance and originality). The other four factors target the experience involving the settings, the tools and the participants' experience (easiness of use - the inverse of cognitive effort; focus on activity; fun or enjoyment during the activity; productivity - whether the activity and the result were considered productive; and collaboration - involving the support for social interaction among the participants). The 5-point Likert scale adopted varies from 'I strongly disagree' (-2) to 'I strongly agree' (+2). Zero stands for no preference or no answer. All the participants filled the forms immediately after each session.

Results. The overall results indicate a positive assessment of the experience (figure 3). Strikingly, both musicians and non-musicians gave the highest rating to collaboration support $(2.00 \pm 0.00)$. Enjoyment was also highly rated with little variation among sessions $(1.91 \pm 0.30)$. Easiness of use got high ratings by all subjects except one $(1.73 \pm 0.90)$. The other two descriptors of the experience got positive ratings but higher standard deviations: focus $(1.64 \pm 0.50)$ and productivity $(1.55 \pm 0.69)$. Finally, the musical product was described as being creative, but this result was not uniform across subjects: relevance $1.55 \pm$ $0.52)$ and originality $(1.64 \pm 0.50)$. 
Figure 3. Results of the Provocative Synthesis // experiment for 11 iterations by 4 subjects per session. Data collected through the CSI-NAP protocol.

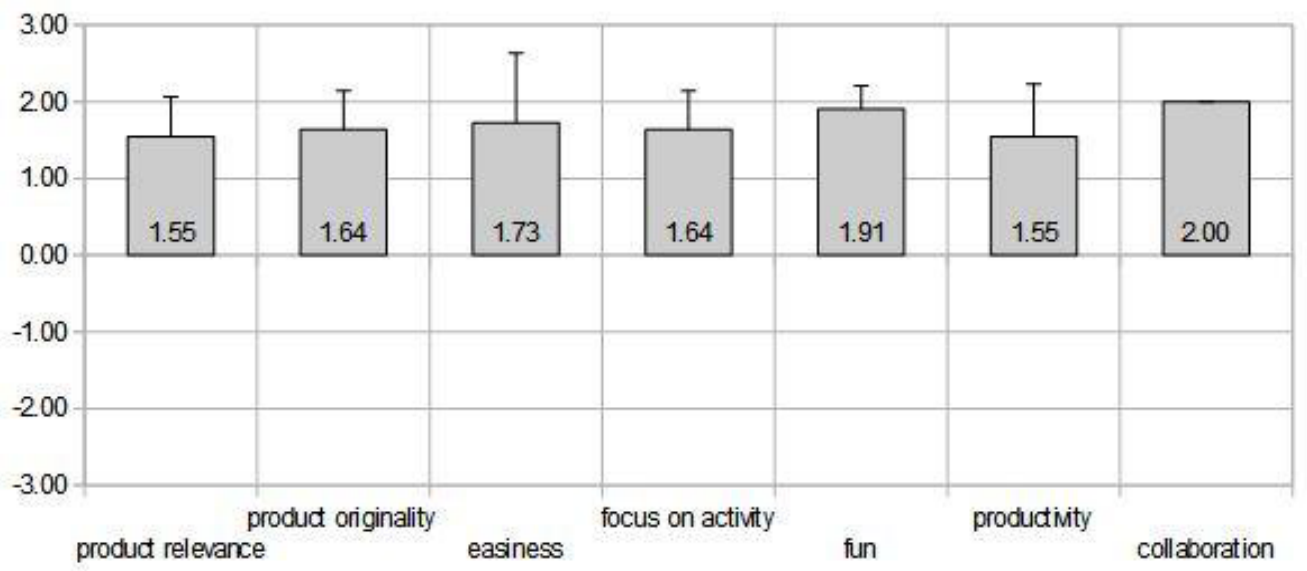

A description of the observations done throughout the sessions may help to give context to the results. The choice of the experimental settings somehow facilitated the initial contact with the subjects. In contrast with previous experiments in everyday musical creativity (KELLER et al., 2013b; KELLER et al., 2015b; PINHEIRO DA SILVA et al., 2014), Provocative Synthesis II involved interactions among professional musicians and laypeople. Previous experiments focusing on creative activities outside of musical venues involved difficulties in drafting participants for the tasks. This was not the case in this experiment. During the activities, we observed that a majority of store visitors were curious and interested in participating in the experience. While novices are generally reluctant to get involved in activities with non-musicians, in this case the possibility of participating in a creative activity with experienced musicians may have sparked their interest.

Limitations. Despite the promising avenue opened by the initial results, several difficulties still need to be addressed. Given the amount of equipment involved, technical preparations become tricky. The multiuser mixer is an effective bridge to integrate instrumental sources with ubiquitous music tools, such as mixDroid. But the dependence on wires and plugs compromises the portability of the system. A combination of wireless connectivity and software-based multiuser mixing might help to increase the mobility of the setup. Another limitation of the study is the small number of sonic resources used by the casual participants. This variable may be related to the profile of the user or to the time available for exploration. In this case, the objective was to assess the ability of the participants to create collaborative sonic products without extended preparation. Hence, it is not possible to determine whether the subjects needed more time or a different kind of support.

Contributions. The high ratings given to the collaboration factor indicate that both the musicians and the untrained subjects felt they were contributing effectively to the musical result. Neither the characteristics of the settings nor the creative products conform to the expected patterns of a professional musical experience. Consequently, these results cannot be classified as a professional-creativity musical outcome (cf. KELLER et al., 2014b for a theoretical discussion of this issue). Furthermore, the high level of collaboration reported here was not observed in other everyday creative activities (KELLER et al., 2013b, PINHEIRO DA SILVA et al., 2013). The results may be interpreted as an indication that the musical experiences at the fringe of professional and everyday creativity open opportunities for effective contributions both from musicians and novices. 


\section{Methodological issues in ubimus}

Ubimus experiments can be criticized from three angles. The first criticism entails the number of subjects per experiment. Studies have ranged from six to 67 subjects. Longitudinal studies in musical creativity usually demand detailed observations of multiple activities in various contexts. The profile of the participants is an important factor. Thus, unless the study includes subjects with diverse educational and musical experiences from varied social contexts, the conclusions have to be limited to the profile of the chosen population. Given this constraint, it makes sense to carry out multiple small-sized (subject-wise) studies. As long as the methods are consistent among the various studies, more general conclusions can be drawn by carrying out meta-analyses of the multiple small-scale studies.

The second criticism targets the data-gathering process. This is a valid concern though it has to be placed within the context of the current efforts to increase the ecological validity of the experiments by carrying out data collection "in the wild." Human-computer interaction literature has adopted a loose interpretation of this term. For example, experiments with full access to network resources, wireless support and unconstrained use of electrical power have been called in the wild. Some ubimus experiments have relied on access to the world wide web (MILETTO et al., 2011; VAN TROYER, 2014). And others have employed local networks (BROWN et al., 2014). But there are also have been experiments involving usage of portable devices that engaged users without the need of network or wireless support (KELLER et al., 2010; PINHEIRO DA SILVA et al., 2013; RADANOVISCK et al., 2011). The experiments were carried out in a variety of settings, including transitional spaces that did not provide easy access to electricity - such as parks and streets. The lack of electrical power did not impact the experiments because the activities were limited to durations of less than an hour. But it is not unreasonable to expect that future ubimus studies will involve harsh conditions such as those found in the Amazonian jungle (KELLER, 2004) or the North African desert (BURTNER, 2011). Hence, the data gathering technique has to take into account the settings chosen for the experiment. Network or wireless services cannot be taken as given. And for experiments that target harsh conditions, special arrangements have to made to ensure ample storage space and periodic access to electrical power. Given these demands, low-tech, highly reliable methods - such as printed forms - may end up being better tools for data gathering than techniques that demand permanent internet access or power-hungry devices.

The third methodological conundrum involves the choice between qualitativeand quantitative techniques. The pioneering ubimus studies - carried out between 2007 and 2014 - have generally adopted a hybrid approach. Quantitative data was gathered but given the lack of well-trodden methods, the objective has been to explore multiple settings and resources to identify possible drawbacks or opportunities for further study. This practice paid off. Several proposals featured in the Workshops on Ubiquitous Music (UbiMus) have triggered new venues of research. Regarding the development tools, the Mobile Csound Platform was initially featured in the 2012 UbiMus (FARIAS et al., 2014; LAZZARINI et al., 2012). Conceptual approaches - such as the patterns for musical interaction - were proposed and discussed in various ubimus workshops (FLORES et al., 2010; FLORES et al., 2012). Exploratory artistic paradigms - such as the ecologically grounded creative practices - were proposed as a focus for ubimus research (KELLER et al., 2014a). They have been taken up by practitioners outside of the ubimus community (ALIEL; FORNARI, 2014; CONNORS, 2015). But of course, exploratory methods eventually give way to targeted and quantifiable data collection. Recent proposals indicate two trends. On one hand, refined tools for data 
gathering seem to be necessary to gauge results of health and human development applications of ubimus (TIMONEY et al., 2015). It is possible that physiological sensors will serve as effective complements of on-site observations and subject-based questionnaires. On the other hand, longitudinal studies might demand long-term data gathering to elucidate the mechanics of artistic decision making, making it very difficult to apply data-intensive methods (Keller et al., 2014b).

\section{Challenges for future ubimus endeavors}

A recent review of musical creative practices (KELLER et al., 2013c) mentions four trends that demand stronger theoretical and methodological frameworks: (1) change of focus from creative products to processes (MARSDEN, 2012); (2) increased reliance on information technology support (TRUAX, 2002); (3) increased importance of local resources in creative activities (KELLER, 2012); (4) a shift from prescriptive models to descriptive and predictive models (BARREIRO; KELLER, 2010; FERRAZ; KELLER, 2014; KELLER et al., 2014b). The design strategies discussed in this paper provide examples of creative decision making grounded on local material resources. The two support metaphors proposed in this paper enhance the available set of techniques to handle these resources. The impact of ubimus research on current creativity theories falls beyond the scope of this paper, but it has been addressed by Ferraz and Keller (2014), Keller et al. (2011), Keller et al. (2014) and Keller and Lazzarini (2017). In this section I will point to four issues that have been unveiled by ubimus experiments as viable research endeavors: everyday musical creativity, lay-musician interaction, design for sustainability, and design for distributed creativity in creative practice.

Everyday musical creativity. The emergence of everyday musical creativity as a worthwhile social phenomenon provides grounding for Truax's (2015) assertion that current musical practices raise the demands for technological support (item 2 of the musical creative practices review). Little-c music making can hardly exist without the assistance of mobile and ubiquitous technology. Wireless networks, portable devices and embedded technologies constitute potential enablers to foster music making almost anywhere (PIMENTA et al., 2014). The time tagging studies reviewed in this paper indicate a pressing need for an experience-based understanding of the implications of everyday creative practice. The impact of the local environment was consistently documented either as a positive or as a negative influence on the participants'performance. Outdoor spaces got positive evaluations when compared to studio settings and domestic spaces were preferred when compared with commercial spaces. But the assessments were not uniform across all factors. The concept of everyday musical creativity that emerges from recent ubimus studies widens the geographical availability of spaces for music making by including creative phenomena which are not linked to artistic venues, enhancing the access by stakeholders that have been traditionally excluded from creative practice.

Lay-musician interaction. The importance of the creative process is highlighted by the lay-musician interaction phenomenon observed in the stripe metaphor study (item 1 of the musical creative practices review). Despite the increased levels of engagement by naive participants, it is not yet clear how to address the demands of professional stakeholders without a negative impact on novices' performance. The strategy employed in this study involved restrictions on the type of musical material - through the use of verbal instructions and of a precomposed rhythmic soundtrack - while keeping the freedom of action for the casu- 
al participants. Effective support may demand a combination of fixed resources and open procedures. A promising method - featuring a mix of predesigned resources and free procedures - is actively pursued by ecologically grounded comprovisational proposals (ALIEL et al., 2015). How much flexibility and what level of guidance are necessary are questions to be answered through multiple iterations of designs and experiments.

An important flag raised by the Provocative Synthesis II study is the potential for exploration of an inclusive form of social engagement involving both proficient partners and casual participants in creative musical activities. Acoustic musical instruments demand long periods of training to achieve minimally rewarding artistic results. This requirement is aligned with the profile of professional practice. But casual music creators without the necessary domain-specific knowledge may not be able to contribute on an equal footing with musicians. The results of the Provocative Synthesis II study point to good levels of engagement when both musicians and casual participants are involved. But support for lay-musician interaction may imply tailoring for specific needs.

Design for sustainability. Technological support for pervasive musical activities increases the difficulties of the design tasks on two fronts. Ubimus systems may enhance the users' creative potential by giving access to local material and social resources (KELLER et al., 2011a; KELLER et al., 2014b) (related to item 2 of the creative musical practices review). But easiness of use does not guarantee wide accessibility and sustainability (BLEVIS, 2007). The push toward wider accessibility to resources could introduce unintended demands that restrict the systems' adoptability. Custom-made, special purpose hardware interfaces - such as those proposed in tangible user interface design (FITZMAURICE et al., 1995) - may meet the requirements of transparency and naturalness reducing the cognitive load of complex tasks (KAHNEMAN, 1973; SWELLER, 1988). In this case, the catch lies in the financial toll. Special-purpose systems are difficult to distribute and maintain. Consequently, the user base is narrowed by the increased costs of the hardware. Thus, one of the challenges of ubimus design is to provide sustainable strategies for complex creative tasks without impacting the usability of the systems.

A set of strategies proposed in previous ubimus design projects may open a path to more sustainable and usable solutions. Two techniques worth considering are hardware repurposing (FLORES et al., 2010; HUANG; TRUONG, 2008; VIEIRA et al., 2012) and rapid prototyping (KELLER et al., 2011a; KELLER et al., 2013a; LAZZARINI et al., 2014). As exemplified in the mixDroid series of prototypes, consumer-class mobile devices - such as cellular telephones and portable tablets - can be repurposed for musical tasks. Given the lack of standard support for audio and musical data formats on mobile platforms, the initial ubimus developments were feasible but complex and counter-intuitive (FLORES et al., 2010; RADANOVITSCK et al., 2011). Recent advances have paved the way to a wider range of mobile and distributed platforms (BRINKMANN, 2012; ESSL; ROHS, 2009; LAZZARINI et al., 2012). Through an iterative approach to design - involving both creative musical activities and creativity support assessments - rapid prototyping techniques have been tailored for ubiquitous contexts. Given that ubimus research targets both interaction and signal processing, flaws that arise from coordination among these two processes can be identified early within the design cycle. Furthermore, on-site usage in full-blown musical activities uncovers opportunities for creative exploration of the software AND of the environment.

Design for distributed creativity. A revised notion of agency is necessary to account for the socially distributed resources involved in community-based creative activity. There 
are two aspects to be considered. On one hand, as ecologically grounded creative practice proposals have shown (BURTNER, 2005; DI SCIPIO, 2008; KELLER, 2000; KELLER; CAPASSO, 2006), musical activities are embedded. That is, they do not rely only on the cognitive resources of the participants. Their outcomes depend on design properties arising from interactions among material resources and behavioral resources. Behaviors change materials and materials change behaviors yielding a process of affordance formation (GIBSON, 1977; KELLER, 2000). When this process impacts the way the material resources are employed to support creativity, the dynamic relationships among resources and agents become relational properties (KELLER et al., 2015a, KELLER et al., 2015b). Complementarily, musical creative activities are social. This means that the resources are not limited by the experiential knowledge of a single creator - knowledge is accumulated and distributed among agents, sometimes forming a community of practice (PIMENTA et al. 2012).

Summing up, I have addressed four issues that emerge as possible research targets for ongoing ubimus projects - everyday musical creativity, lay-musician interaction, design for sustainability and design for distributed creativity. The experiments reported and summarized in this paper point to the metaphors for creative action as viable strategies for support of creative musical activities that involve the participation of non-musicians or that take place in settings not meant for music making. Aside from the positive impact of the proposals reviewed above - including applications in artistic settings (ALIEL et al., 2015; CAPASSO et al., 2013; CONNORS, 2017) and in educational settings (BROWN et al., 2014; LIMA et al., 2012; PALAIGEORGIOU; POULOULIS, 2017; THORGERSEN, 2014), ubimus is a growing area of research that may provide contributions to multiple fields that demand fresh theoretical and methodological views on music making. One example is the development of the Internet of Musical Things (IoMusT - KELLER; LAZZARINI, 2017; TURCHET et al.m 2017). The IoMusT is a network-enabled infrastructure featuring multiple physical objects that hold a potential for local and remote access during collaborative musical activities. One interesting aspect of this set of tools is its ability to incorporate and to repurpose a variety of everyday objects for musical ends. Consequently, the IoMusT could help to fulfill the agenda of ubimus sustainable support infrastructure. Another application of ubimus design strategies involves the incentive of positive and healthy activities by means of creative musical endeavors. Preliminary studies have been carried out with elderly subjects, involving audio mixing during short walks. Results indicate that ubimus activities help sedentary subjects who need motivation for physical activity to adopt positive changes in their routine. Creativity support strategies have also been applied to foster music making by cognitively challenged participants. Very encouraging results were obtained in preliminary studies involving adults with serious cognitive challenges, with no previous technological experience and lacking written language skills. These results and the variety of experiments carried out during a decade of ubimus research unveil new fields of application, hinting at exciting developments in the foreseeable future.

\section{Acknowledgements}

Research partially supported by a CNPq Productivity Grant 2015-2018. Special thanks to Edemilson Ferreira for his collaboration on this project.

\section{References}

Aliel, L.; FornARI, J. Creating an ecologically modeled performance through the remote manipulation of multiple soundscapes. In: Ferneda, E.; Cabral, G.; Keller, D. (eds.): Proceedings of the 
Brazilian Symposium on Computer Music (SBCM 2013). Brasília, DF: SBC, 2013.

Aliel, L.; Keller, D.; Costa, R. Comprovisação: Abordagens Desde a Heurística Estética em Ecocomposição. In: Proceedings of the Brazilian Symposium on Computer Music (SBCM 2015). Campinas, SP: SBC, 2015.

BARreiro, D. L.; KeLLer, D. Composing with sonic models: fundamentals and electroacoustic applications (Composição com modelos sonoros: fundamentos e aplicações eletroacústicas). In: Keller, D.; Budasz, R. (eds.), Criação musical e tecnologias: Teoria e prática interdisciplinar. Goiânia, GO: Editora ANPPOM, 2010, 97-126.

Beghetto, R. A.; Kaufman, J. C. Toward a broader conception of creativity: A case for "mini-c" creativity. In: Psychology of Aesthetics Creativity and the Arts 1 (2), 2007, 73-79.

Bessa, W. R. B.; Keller, D.; Farias, F. M.; Edemilson Ferreira, Pinheiro da Silva, F.; Pereira da SilvA, V. SoundSphere v.1.0: Documentação e análise dos primeiros testes. In: Anais do Simpósio Internacional de Música na Amazônia (IV SIMA). Porto Velho, RO: UNIR, 2015.

Bittencourt, M. A. Damián Keller and Rogério Budasz (eds.), Music Creation and Technologies: Interdisciplinary Theory and Practice. Série Pesquisa em Música no Brasil, vol. 2. Goiânia: Anppom, 2010. (ISBN: 978-85-63046-01-7).

Blevis, E. Sustainable interaction design: invention \& disposal, renewal \& reuse. In: Proceedings of the SIGCHI Conference on Human Factors in Computing Systems. New York: ACM, 2007, 503-512.

Brinkmann, P. Making Musical Apps: Using the Libpd Sound Engine. New York: O'Reilly \& Associates Incorporated, 2012.

Brown, A. R.; Stewart, D.; Hansen, A.; Stewart, A. Making meaningful musical experiences accessible using the iPad. In: Keller, D.; Lazzarini, V.; Pimenta, M. S. (eds.), Ubiquitous Music. Heidelberg Berlin: Springer International Publishing, 2014, 65-81.

Burtner, M. Ecoacoustic and shamanic technologies for multimedia composition and performance. Organised Sound 10 (1), 2005, 3-19.

Burtner, M. EcoSono: Adventures in interactive ecoacoustics in the world. Organised Sound 16 (3), 2011, 234-244.

Capasso, A.; Keller, D.; Tinajero, P. Palafito / Palafita / Home-on-stilts 2.0 [Ubiquitous Music Work]. Denver, CO: Museum of the Americas, 2013.

Connors, T. M. Audiovisual installation as ecological performativity. In: Proceedings of the 21st International Symposium on Electronic Art (ISEA2015). Vancouver, Canada: ISEA, 2015.

Dewey, J. Art As Experience. New York, NY: Perigee Books, 1934.

Di ScIPIO, A. Émergence du son, son d'emergence: Essai d'épistémologie expérimentale par un compositeur. Intellectica 48-49, 2008, 221-249.

Eaglestone, B.; Ford, N.; Brown, G. J.; Moore, A. Information systems and creativity: An empirical study. Journal of Documentation 63 (4), 2007, 443-464.

EssL, G.; RoHs, M. Interactivity for mobile music-making. Organised Sound 14, 2009, 197-207.

Farias, F. M.; Keller, D.; Pinheiro Da Silva, F.; Pimenta, M. S.; Lazzarini, V.; Lima, M. H.; CostaLONGA, L.; JohANN, M. Everyday musical creativity support: mixDroid second generation (Suporte para a criatividade musical cotidiana: mixDroid segunda geração). In: KeLLER, D.; LiMA, M. H.; Schiavoni, F. (eds.), Proceedings of the V Workshop on Ubiquitous Music (V UbiMus). Vitória, ES: Ubiquitous Music Group, 2014. 
Ferraz, S.; KelLer, D. Preliminary proposal of the In-group, Out-group model of collective creation (MDF: Proposta preliminar do modelo dentro-fora de criação coletiva). Cadernos de Informática 8 (2), 2014, 57-67.

Fitzmaurice, G. W.; Ishit, H.; Buxton, W. Bricks: Laying the foundations for graspable user interfaces. In Proceedings of the ACM SIGCHI Conference on Human Factors in Computing Systems (CHI'95), 1995, 442-449.

Flores, L.; Miletto, E.; Pimenta, M.; Miranda, E.; Keller, D. Musical interaction patterns: Communicating computer music knowledge in a multidisciplinary project. In: Proceedings of the 28th ACM International Conference on Design of Communication. New York, NY: ACM, 2010, 199-206.

Gibson, J. J. The theory of affordances. In: Shaw, R.; Bransford, J. (eds.), Perceiving, Acting, and Knowing: Toward an Ecological Psychology. Mahwah, NJ: Lawrence Erlbaum Associates, 1977, 67-82.

Grant, K. A. Tacit knowledge revisited: We can still learn from Polanyi. The Electronic Journal of Knowledge Management 5 (2), 2007.

Huang, E. M.; Truong, K. N. Breaking the disposable technology paradigm: opportunities for sustainable interaction design for mobile phones. In: Proceedings of the Twenty-Sixth Annual SIGCHI Conference on Human Factors in Computing Systems (CHI '08), 2008, 323-332. New York, NY: ACM.

Kahneman, D. Attention and Effort. Englewood Cliffs, New Jersey: Prentice-Hall, 1973.

Kaufman, J. C.; Beghetto, R. A. Beyond big and little: The four c model of creativity. Review of General Psychology 13 (1), 2009, 1-12.

KELLER, D. Compositional processes from an ecological perspective. Leonardo Music Journal 10, 2000, 55-60.

KeLLeR, D. Challenges for a second decade of ubimus research (part 1) (Keynote). In: Proceedings of the Brazilian Symposium on Computer Music (SBCM 2017). São Paulo, SP: SBC, 2017.

Keller, D.; Barreiro, D. L.; Queiroz, M.; Pimenta, M. S. Anchoring in ubiquitous musical activities. In: Proceedings of the International Computer Music Conference. Ann Arbor, MI: MPublishing, University of Michigan Library, 2010, 319-326.

Keller, D.; Barros, A. E. B.; Farias, F. M.; Nascimento, R. V.; Pimenta, M. S.; Flores, L. V.; Miletto, E. M.; Radanovitsck, E. A. A.; Serafini, R. O.; Barraza, J. F. Ubiquitous music: Concept and background (Música ubíqua: Conceito e motivação). In: Proceedings of the National Association of Music Research and Post-Graduation Congress - ANPPOM. Goiânia, GO: ANPPOM, 2009a, 539-542.

Keller, D.; Budasz, R. (eds.) Music Creation and Technologies: Interdisciplinary Theory and Practice (Criação Musical e Tecnologias: Teoria e Prática Interdisciplinar). Goiânia, GO: Editora ANPPOM, vol. 2, 2010. (ISBN 978-85-63046-01-7)

Keller, D.; Capasso, A. New concepts and techniques in eco-composition. Organised Sound 11 (1), 2006, 55-62.

Keller, D.; Capasso, A.; Tinajero, P.; Flores, L. V.; Pimenta, M. S. Green Canopy: On The Road [Ubiquitous Music Work]. In: Proceedings of XII Brazilian Symposium on Computer Music (SBCM 2009). Porto Alegre, RS: SBC, 2009b.

Keller, D.; Ferreira da Silva, E.; Pinheiro da Silva, F.; Lima, M. H.; Pimenta, M. S.; Lazzarini, V.: Everyday musical creativity: An exploratory study with vocal percussion sounds (Criatividade musical cotidiana: Um estudo exploratório com sons vocais percussivos). In: Proceedings of the 
National Association of Music Research and Post-Graduation Congress - ANPPOM. Natal, RN: ANPPOM, 2013a.

Keller, D.; Flores, L. V.; Pimenta, M. S.; Capasso, A.; Tinajero, P. Convergent trends toward ubiquitous music. Journal of New Music Research 40 (3), 2011a, 265-276.

KelLer, D.; Lazzarini, V. Ecologically grounded creative practices in ubiquitous music. Organised Sound 22, 2017, 61-72.

Keller, D.; Lazzarini, V.; Pimenta, M. S. (eds.). Ubiquitous Music. Berlin and Heidelberg: Springer International Publishing, vol. XXVIII, 2014a.

Keller, D.; LazZarini, V.; Pimenta, M. S.: Ubimus through the lens of creativity theories. In: KeLLER, D.; Lazzarini, V.; Pimenta, M. S. (eds.), Ubiquitous Music. Berlin and Heidelberg: Springer International Publishing, 2014b, 3-23.

KeLLER, D.; Lima, M. H. Supporting everyday creativity in ubiquitous music making. In: Kostagiolas, P.; Martzoukou, K.; Lavranos, C. (eds.): Trends in Music Information Seeking, Behavior, and Retrieval for Creativity. Vancouver, BC: IGI Global Press, 2016.

Keller, D.; Miletto, E. M.; Otero, N. Creative surrogates: Supporting decision-making in ubiquitous musical activities. In: Proceedings of the 3rd International Conference on Computation, Communication, Aesthetics and $X(x C o A x$ 2015). Glasgow, Scotland: xCoAx, 2015a.

Keller, D.; Otero, N.; Lazzarini, V.; Pimenta, M. S.; Lima, M. H.; Johann, M.; Costalonga, L. L. Interaction aesthetics and ubiquitous music. In: Zagalo, N.; Blanco, P. (eds.), Creativity in the Digital Age. Berlin and Heidelberg: Springer, 2015b, 91-105.

Keller, D.; Pinheiro da Silva, F.; Ferreira da Silva, E.; Lazzarini, V.; Pimenta, M. S. Opportunistic design of ubiquitous music systems: The impact of anchoring on creativity (Design oportunista de sistemas musicais ubíquos: $\mathrm{O}$ impacto do fator de ancoragem no suporte à criatividade). In: Ferneda, E.; Cabral, G.; Keller, D. (eds.), Proceedings of the XIV Brazilian Symposium on Computer Music (SBCM 2013). Brasília, DF: SBC, $2013 \mathrm{~b}$.

Keller, D.; Pinheiro da Silva, F.; Giorni, B.; Pimenta, M. S.; Queiroz, M. Spatial tagging: an exploratory study (Marcação espacial: estudo exploratório). In: Proceedings of the 13th Brazilian Symposium on Computer Music (SBCM 2011). Vitória, ES: SBC, $2011 b$.

Keller, D.; Quaranta, D.; Sigal, R. Special Volume Sonic Ideas: Musical Creativity (Volume Especial Sonic Ideas: Criatividade Musical), Vol. 10. Morelia, Michoacán: Centro Mexicano para la Música y las Artes Sonoras, 2013c.

Keller, D.; Timoney, J.; Costalonga, L.; Capasso, A.; Tinajero, P.; Lazzarini, V.; Pimenta, M. S.; Lima, M. H.; Johann, M. Ecologically grounded multimodal design: The Palafito 1.0 study. In: Proceedings of the International Computer Music Conference (ICMC 2014). Ann Arbor, MI: MPublishing, University of Michigan Library, 2014c, 1677-1684.

Keller, D.; Truax, B. Ecologically based granular synthesis. In: Proceedings of the International Computer Music Conference. Ann Arbor, MI: MPublishing, University of Michigan Library, 1998, 117-120.

Kozbelt, A.; Beghetto, R. A.; Runco, M. A. Theories of creativity. In: Kaufman, J. C.; Sternberg, R. J. (eds.), The Cambridge Handbook of Creativity. Cambridge, UK: Cambridge University Press, 2010, 20-47.

Lazzarini, V.; Keller, D.; Kuhn, C.; Pimenta, M.; Timoney, J. Prototyping of ubiquitous music ecosystems. Journal of Cases on Information Technology 17 (4), 2015.

Lazzarini, V.; Keller, D.; Pimenta, M.; Timoney, J. Ubiquitous music ecosystems: Faust programs in Csound. In: Keller, D.; Lazzarini, V.; Pimenta, M. S. (eds.), Ubiquitous Music. Berlin and Hei- 
delberg: Springer International Publishing, 2014, 129-150.

Lazzarini, V.; Yi, S.; Timoney, J.; Keller, D.; Pimenta, M. S. The Mobile Csound Platform. In: Proceedings of the International Computer Music Conference (ICMC 2012). Ann Arbor, MI: MPublishing, University of Michigan Library, 2012, 163-167.

LEwis, G. E. Too many notes: computers, complexity and culture in Voyager. Leonardo Music Journal 10, 2000, 33-39.

Lima, M. H.; Keller, D.; Pimenta, M. S.; Lazzarini, V.; Miletto, E. M. Creativity-centred design for ubiquitous musical activities: Two case studies. Journal of Music, Technology and Education 5 (2), 2012, 195-222.

Marsden, A. "What was the question?": Music analysis and the computer. In: GiBson, L.; CraWFord, T. (eds.), Modern Methods for Musicology: Prospects, Proposals, and Realities. London: Ashgate Publishing, 2012, 137-153.

Miletto, E. M.; Pimenta, M. S.; Bouchet, F.; Sansonnet, J.-P.; Keller, D. Principles for music creation by novices in networked music environments. Journal of New Music Research 40 (3), 2011, 205-216.

Palaigeorgiou, G.; Pouloulis, C. Orchestrating tangible music interfaces for in-classroom music learning through a fairy tale: The case of ImproviSchool. Education and Information Technologies, 2017. (DOI: 10.1007/s10639-017-9608-z)

Pimenta, M. S.; Flores, L. V.; Capasso, A.; Tinajero, P.; Keller, D. Ubiquitous music: concept and metaphors. In: Proceedings of the Brazilian Symposium on Computer Music (XII SBCM). Recife, PE: SBC, 2009, 139-150.

Pimenta, M. S.; Keller, D.; Flores, L. V.; Lima, M. H.; LazZarini, V. Methods in Creativity-Centred Design for Ubiquitous Musical Activities. In: Keller, D.; Lazzarini, V.; Pimenta, M. S. (eds.), Ubiquitous Music. Berlin and Heidelberg: Springer International Publishing, 2014, 25-48.

Pimenta, M. S.; Miletto, E. M.; Keller, D.; Flores, L. V. Technological support for online communities focusing on music creation: Adopting collaboration, flexibility and multiculturality from Brazilian creativity styles. In: AzAB, N. A. (ed.), Cases on Web 2.0 in Developing Countries: Studies on Implementation, Application and Use. Vancouver, BC: IGI Global Press, 2012.

Pinheiro da Silva, F.; Keller, D.; Ferreira da Silva, E.; Pimenta, M. S.; Lazzarini, V. Everyday musical creativity: Exploratory study of ubiquitous musical activities (Criatividade musical cotidiana: Estudo exploratório de atividades musicais ubíquas). Música Hodie 13, 2013, 64-79.

Pinheiro da Silva, F.; Pimenta, M. S.; Lazzarini, V.; Keller, D. Time tagging in its niche: Engagement, explorability and creative attention (A marcação temporal no seu nicho: Engajamento, explorabilidade e atenção criativa). Cadernos de Informática 8 (2), 2014.

Polanyi, M. Personal Knowledge: Towards a Post-critical Philosophy. London: Routledge, 1958.

Radanovitsck, E. A. A.; Keller, D.; Flores, L. V.; Pimenta, M. S.; Queiroz, M. mixDroid: Time tagging for creative activities (mixDroid: Marcação temporal para atividades criativas). In: Costalonga, L.; Pimenta, M. S.; Queiroz, M.; Manzolli, J.; Gimenes, M.; Keller, D.; Faria, R. R. (eds.), Proceedings of the XIII Brazilian Symposium on Computer Music (SBCM 2011). Vitória, ES: SBC, 2011.

Ribeiro Netto, A.; Castheloge, L.; Oliosi, A.; Mateus, A.; Costalonga, L.; Coura, D. Memory Tree: Multimedia Interactive Installation (Árvore das Memórias: Instalação Multimídia Interativa). In: Proceedings of the XV Brazilian Symposium on Computer Music (SBCM 2015). Campinas, SP: SBC, 2015, 76-82.

Richards, R.; Kinney, D.; Benet, M.; Merzel, A. Assessing everyday creativity: Characteristics of 
the lifetime creativity scales and validation with three large samples. Journal of Personality and Social Psychology 54, 1988, 476-485.

Shneiderman, B.: Creativity support tools: accelerating discovery and innovation. Communications of the ACM 50 (12), 2007, 20-32.

Simonton, D. K. History, chemistry, psychology, and genius: An intellectual autobiography of historiometry. In: Runco, M. A.; Albert, R. S. (eds.), Theories of Creativity. Newbury Park, CA: Sage, 1990, 92-115.

SwELLER, J. Cognitive load during problem solving: Effects on learning. Cognitive Science 12 (2), 1988, 257-285.

TANAKa, A. Sensor-based musical instruments and interactive music. In: Dean, R. T. (ed.): The Oxford Handbook of Computer Music. New York, NY: Oxford University Press, 2009, 233-257.

Thorgersen, C. F. Lose control, listen to each other, and create - understanding cooperative music making from a chiasmatic perspective. Reconstruction 14 (2), 2014.

Timoney, J.; Lazzarini, V.; Ward, T.; Villing, R.; Conway, E.; CzesaK, D. The Beathealth project: Synchronizing movement and music. In: Proceedings of the $V$ Workshop on Ubiquitous Music (V UbiMus). Vitória, ES: Ubiquitous Music Group, 2014.

van Troyer, A. Repertoire Remix in the Context of Festival City. In: Keller, D.; Lazzarini, V.; PIMENTA, M. S. (eds.), Ubiquitous Music. Berlin and Heidelberg: Springer International Publishing, 2014, 51-63.

TRUAX, B. Genres and techniques of soundscape composition as developed at Simon Fraser University. Organised Sound 7 (1), 2002, 5-14.

Truax, B. Music, soundscape and acoustic sustainability. Moebius Journal 1, 2012.

Truax, B. Paradigm shifts and electroacoustic music: Some personal reflections. Organised Sound 20, 2015, 105-110.

Turchet, L.; Fischione, C.; Barthet, M. Towards the Internet of Musical Things. In: Proceedings of the Sound and Music Computing Conference (SMC 2017). Helsinki, Finland: Aalto University, 2017.

Vasarely, V. Notes pour un manifeste. Le Mouvement. Paris: Glaerie Denise René, 1955. http://vasarelyparvasarely.com/

Vieira, V. A.; Farias, F. M.; Keller, D.; LazZarini, V.; Pimenta, M. S. Reaproveitamento de dispositivos legados em práticas criativas: $\mathrm{O}$ caso Keyboard Hero. In: Anais da Escola de Informática da Região Norte 3 (ERIN3). Porto Velho, RO: SBC, 2012.

Wessel, D.; Wright, M. Problems and prospects for intimate musical control of computers. Computer Music Journal 26 (3), 11-22, 2002.

White, P. JamHub: Personal monitor system. Sound On Sound, October, 2010. http://www.soundonsound.com/sos/oct10/articles/jamhub.htm

Dámian Keller - Possui doutorado em tecnologia e composição musical pela Universidade Stanford (2004) e mestrado interdisciplinar em arte pela Universidade Simon Fraser (1999). Realizou pós-doutoramento em ciência da computação na Universidade Federal do Rio Grande do Sul (2012). Atualmente é professor associado na Universidade Federal do Acre, onde lidera o grupo de pesquisa NAP - Núcleo Amazônico de Pesquisa Musical. Tem experiência nas áreas de computação musical, composição musical, cognição musical, interação humano-computador, atuando principalmente nos seguintes temas: música ubíqua, ecocomposição, design criativo, arte multimídia. É um dos fundadores da rede de pesquisa Grupo de Música Ubíqua 